\title{
SORTING OUT SOLUTIONS TO THE NOW-WHAT PROBLEM
}

\author{
François Jaquet
}

W OULD YOU SAY that donating to charity is right and rape is wrong, that generosity is a virtue and vanity a vice, that children must respect their parents and husbands not beat their wives? Then you are mistaken according to the moral error theory, which takes all moral judgments to be false. On the main variant of the view, these judgments are false because they presuppose the existence of queer nonnatural facts - and these facts are queer because they would generate categorical reasons, i.e., reasons one would have regardless of one's desires. ${ }^{1}$

Some error theories naturally lead to the abandonment of their target judgments. Thus, religious error theorists rarely believe that God is omniscient or that He disapproves of homosexuality. Still, other error theories do not share this eliminativist tendency. We should continue to believe that $1+1=2$ even assuming that all arithmetical beliefs are false because they presuppose the existence of queer arithmetic facts. ${ }^{2}$ The opposite policy would have terrible consequences, which suggests that our arithmetical beliefs are useful regardless of their truth. The moral error theory therefore raises the following question: What should we do with our moral beliefs? Should we get rid of them (as atheists get rid of their religious beliefs) or retain them (as we would retain our arithmetical beliefs if we discovered that they are false)? This question is known as the "nowwhat problem" for moral error theorists. ${ }^{3}$

1 Mackie, Ethics; Joyce, The Myth of Morality.

2 Field, Realism, Mathematics, and Modality.

3 Lutz, "The 'Now What' Problem for Error Theory." Two clarifications are in order. First, as opposed to a moral question, which would make no sense for error theorists to ask, this question presupposes only the existence of hypothetical reasons, i.e., reasons that depend on their bearer's desires (Joyce, The Myth of Morality, 221; Lutz, “The 'Now What' Problem for Error Theory," 353; Svoboda, "Why Moral Error Theorists Should Become Revisionary Moral Expressivists," 50). It simply does not arise for error theorists who deny the existence of such reasons (e.g., Streumer, Unbelievable Errors). Second, this question does not presuppose the truth of doxastic voluntarism, i.e., the view that we have direct control over our 
Until recently, three solutions had been advanced in the literature. As its name indicates, abolitionism advocates the abolition of our moral beliefs. ${ }^{4}$ No more surprisingly, conservationism advises us to keep our moral beliefs, as if nothing happened. ${ }^{5}$ Finally, fictionalism is a form of revisionism: it recommends that we replace our moral beliefs with fictional attitudes. ${ }^{6}$ Lately, however, two other revisionary theories have emerged in this debate. According to revisionary expressivism, we should replace our current moral beliefs with revised moral judgments constituted by conative attitudes: disapprove of rape instead of believing that rape is wrong. ${ }^{7}$ According to revisionary naturalism, we should replace our current moral beliefs with revised moral judgments constituted by beliefs in natural facts: believe that rape causes significant psychological distress instead of believing that rape is wrong, for instance. ${ }^{8}$

In this paper, I argue that both revisionary expressivism (hereafter, "expressivism") and revisionary naturalism (hereafter, "naturalism") are in the end mere variants of abolitionism. In section 1, I present Toby Svoboda's case for expressivism and Stan Husi's, Matt Lutz's, and Wouter Kalf's case for naturalism. These authors list several desiderata that a suitable solution to the now-what problem should satisfy and then argue that their favorite theory satisfies these desiderata better than abolitionism, conservationism, and fictionalism. In section 2, I contend that, on closer inspection, neither expressivism nor naturalism fares better than abolitionism in these respects: abolitionists can help themselves to all the tools expressivists or naturalists use to satisfy their desiderata. Then, in section 3 , I argue that the pieces of advice put forward by expressivists and naturalists actually amount to forms of abolitionism because there is nothing moral about the attitudes these philosophers say we should replace our moral beliefs with. Finally, in section 4, I show that this argument does not affect these theories merely because they are revisionist, since the main variant of fictionalism does not face

beliefs. The issue is not what to do with our moral beliefs at a given instant but whether to cultivate a disposition to accept moral propositions, as a "life strategy" so to speak (Joyce, The Myth of Morality, 219, 223-24).

4 Hinckfuss, The Moral Society; Garner, "Abolishing Morality"; Ingram, "After Moral Error Theory, After Moral Realism."

5 Olson, Moral Error Theory.

6 Joyce, The Myth of Morality; Nolan et al., "Moral Fictionalism versus the Rest."

7 Svoboda, "Why Moral Error Theorists Should Become Revisionary Moral Expressivists."

8 Husi, "Against Moral Fictionalism”; Lutz, “The 'Now What' Problem for Error Theory”; Kalf, Moral Error Theory. Revisionary expressivism and naturalism should be sharply distinguished from their hermeneutic homonyms, according to which moral judgments already are conative attitudes or beliefs in natural facts. These views do not aim to solve the nowwhat problem since they are incompatible with the error theory. 
it. At the end of the day, force fictionalism is the only truly revisionary solution to the now-what problem.

\section{THE CASES FOR EXPRESSIVISM AND NATURALISM}

Assume with the error theorist that our current moral judgments are beliefs about nonnatural facts. Expressivism is the view that we should replace them with revised moral judgments constituted by conative attitudes. Thus, instead of believing that donating to charity is right, we should approve of donating to charity, and instead of believing that rape is wrong, we should disapprove of rape. Naturalism, by contrast, is the view that we should replace our current moral judgments with revised moral judgments constituted by beliefs about natural facts. It comes in two varieties. On the one hand, the objective naturalist's replacement judgments are beliefs in mind-independent natural facts. Instead of believing that donating to charity is right we should believe that donating to charity maximizes pleasure, and instead of believing that rape is wrong we should believe that rape causes significant distress. On the other hand, the subjective naturalist's replacement judgments are beliefs about our attitudes. Instead of believing that donating to charity is right we should believe that we approve of donating to charity, and instead of believing that rape is wrong we should believe that we disapprove of rape.

According to their respective proponents, expressivism and naturalism are the best solutions to the now-what problem because they meet four desiderata that all former theories failed to satisfy. First, a good solution would have us avoid moral error, for "There is an epistemic tension involved in making utterances that one believes to be false."' To be clear, the reason why we should not knowingly believe false propositions is not fundamentally epistemic. Epistemic reasons are relevant to the now-what problem only indirectly since the "should" in the question is hypothetical. Rather, it is because believing falsehoods would impede our interests, by providing us with misinformed desires, that we should avoid doing so. ${ }^{10}$

Second, a good solution to the now-what problem would give us reasons to act-both motivating and normative reasons; it would let our moral judgments move us to some extent and provide us with considerations that favor certain courses of action. This should come as no surprise since moral thought is es-

9 Svoboda, "Why Moral Error Theorists Should Become Revisionary Moral Expressivists," 57; see also Lutz, "The 'Now What' Problem for Error Theory," 355; Husi, "Against Moral Fictionalism," 88.

10 Joyce, The Myth of Morality, 179. 
sentially practical. As Svoboda puts it, "intrapersonal motivation is a feature of morality worth preserving because it bolsters one's commitment to act for certain ends, increases one's self-control, and helps overcome weakness of will."11 Should we replace our moral beliefs with motivationally inert attitudes, the moral practice would become worthless. Besides, morality would be even more effective if it provided us with normative reasons to act. ${ }^{12}$

Third, a good solution to the now-what problem would make it possible for two subjects to have a genuine moral disagreement. In other words, it would sidestep the disagreement problem often raised against speaker subjectivism. Suppose that Jim judges that homosexuality is wrong while Pam judges that it is right. According to speaker subjectivism, he thereby means that he disapproves of homosexuality while she thereby means that she approves of homosexuality. As a result, Jim and Pam's disagreement is merely apparent; they are talking past each other. But this is extremely implausible, as Jim and Pam clearly disagree in this case. The idea behind the third desideratum is that a solution to the nowwhat problem should entail that two subjects would genuinely disagree when one of them would judge that an act is wrong and the other that it is right. For it is on this condition that the revised morality will successfully help us to coordinate our behaviors. ${ }^{13}$

Finally, a good solution to the now-what problem would leave room for moral reasoning. ${ }^{14}$ In particular, it would not bump into the Frege-Geach problem. This problem was initially addressed at hermeneutic expressivism, that is, the claim that moral sentences express conative attitudes. Although the worry concerns meaning more than it does reasoning as such, it is often framed in those terms: this brand of expressivism cannot account for the validity of moral arguments. A nice illustration is provided by moral modus ponens such as: stealing is wrong; if stealing is wrong, then fencing stolen goods is wrong; therefore, fencing stolen goods is wrong. Indeed, if a moral sentence's meaning is to be accounted for in terms of the conative attitude this sentence expresses, then the meaning of "stealing is wrong" cannot remain constant across this argument,

11 Svoboda, "Why Moral Error Theorists Should Become Revisionary Moral Expressivists," 67.

Lutz, “The 'Now What' Problem for Error Theory,” 358.

13 Svoboda, "Why Moral Error Theorists Should Become Revisionary Moral Expressivists," 60; see also Olson, "Getting Real about Moral Fictionalism," 186. Naturalists tend to phrase the third desideratum directly in terms of coordination: a good solution to the now-what problem would help us to solve coordination issues (Husi, "Against Moral Fictionalism," 92; Lutz, "The 'Now What' Problem for Error Theory," 366; Kalf, Moral Error Theory, 162-70).

14 Svoboda, "Why Moral Error Theorists Should Become Revisionary Moral Expressivists," 55; Husi, "Against Moral Fictionalism," 92. 
whose second premise does not express a negative attitude toward stealing. But then the argument is invalid because it commits the fallacy of equivocation. In the present context, the point is slightly different. Because solutions to the nowwhat problem are not in the business of describing the current moral practice, they need not account for the validity of such arguments. The idea is rather that a morality in which such arguments are invalid would be useless.

Expressivists and naturalists insist that the three older solutions to the nowwhat problem fail to satisfy these desiderata. While fictionalism avoids moral error, it does not allow for moral motivation, disagreement, and (in the case of force fictionalism) reasoning. Fictional attitudes would fail to motivate their bearers, disagreement cannot occur between people who accept different fictions, and making a fiction of mutually inconsistent propositions is not inconsistent. Conversely, while conservationism allows for moral motivation, disagreement, and reasoning, it cannot avoid moral error. Given my topic in this paper, I will focus on the contrast between expressivism and naturalism on the one hand and abolitionism on the other. So, how does abolitionism cope with these desiderata? For obvious reasons, it avoids moral error: if we stopped making moral judgments, we would no longer presuppose the existence of queer nonnatural facts. For reasons no less evident, however, abolitionism violates the remaining three requirements: since it involves the abolition of morality, it does not allow for moral motivation, disagreement, or reasoning. All in all, "Moral abolitionism would avoid moral error, but it also misses out on the useful features of morality." ${ }^{\prime 15}$

By contrast, according to Svoboda, expressivism satisfies all four desiderata. First, it avoids moral error: because the revised moral judgments would be conative states rather than beliefs, they would not be false-they would be neither true nor false. As they would not even purport to represent the world, they would not presuppose the existence of queer nonnatural facts. ${ }^{16}$ Second, expressivism allows for moral motivation. Because the revised moral judgments would be conative states, states that are characterized by their world-to-mind direction of fit, they would prompt us to act accordingly. ${ }^{17}$ As conative states, they would also provide us with hypothetical normative reasons, reasons whose existence would depend on them. Third, expressivism allows for the existence of moral disagreements. When Jim judges that homosexuality is wrong while Pam judges 67. 
that it is right, they do not contradict each other in the sense that either of their judgments must be false. Still, they disagree in attitude, just as someone who wants the end of the war and someone who wants the war to continue disagree in attitude even though neither of their attitudes is false. ${ }^{18}$ Finally, expressivism allows for the possibility of moral reasoning. This might come as a surprise since the Frege-Geach problem was originally designed as an objection to hermeneutic expressivism. For his variant of expressivism to avoid the Frege-Geach problem, Svoboda relies on Simon Blackburn's higher-order attitudes account. On this account, to judge that fencing stolen goods is wrong if stealing is wrong is to disapprove of a combination of conative attitudes: disapproving of stealing without disapproving of fencing stolen goods. The modus ponens mentioned above is valid because if one accepts its second premise then one disapproves of accepting its first premise while rejecting its conclusion. ${ }^{19}$ Now, some have objected that this account does not vindicate the argument's validity even though it shows that one must be somehow irrational to accept its premises while rejecting its conclusion. ${ }^{20}$ One might expect Blackburn's solution to face this objection too when applied to revisionary expressivism, but Svoboda denies this:

If we grant that expressivist moral judgments do not admit of logical relations among one another, they still provide good pragmatic reasons to those who hold them (e.g., to adopt or relinquish some moral attitude), and this may be enough to establish the possibility of moral reasoning. ${ }^{21}$

While moral arguments would not be strictly speaking valid in the revised practice, our conative attitudes would allow us to reason about morality.

Naturalism too satisfies all four desiderata, according to its advocates. First, it avoids moral error. Indeed, by contrast with moral beliefs, which presuppose the existence of nonnatural facts, nonmoral beliefs are true whenever the natural facts they purport to represent obtain. Second, naturalism provides us with both motivating and normative reasons to act morally. As Lutz puts it, "While there might not be any moral reasons, the salvaged concept can refer to something that can ground strong non-moral reasons for actions that are commonly considered to be moral."22 Suppose that we would replace our moral beliefs with

Svoboda, "Why Moral Error Theorists Should Become Revisionary Moral Expressivists," 68.

Blackburn, Spreading the Word, 195-96. Svoboda, "Why Moral Error Theorists Should Become Revisionary Moral Expressivists," 69.

Lutz, “The 'Now What' Problem for Error Theory," 369. 
beliefs about our states of approval and disapproval, as suggested by subjective naturalists. Then, assuming a Humean theory of reasons and provided that the replacement judgments are true, they would provide us with motivation and reasons to act. By judging that rape is wrong, you would judge that you disapprove of rape, which would provide you with both a disposition and a hypothetical reason against rape-one grounded in your conative attitude. Third, naturalism allows for the possibility of moral disagreement. Jim and Pam will disagree if he believes that homosexuality causes significant distress while she believes that it is harmless - and they will disagree in attitudes if he believes that he disapproves of homosexuality while she believes that she approves of homosexuality (provided that their beliefs are true). Finally, naturalism makes moral reasoning possible. Nothing unexpected there, since hermeneutic naturalism does not meet the Frege-Geach problem. As long as moral reasoning is made of inferences between beliefs about natural facts, it is plainly possible.

Expressivists and naturalists thus take themselves to put forward views that are not only distinct from but also superior to abolitionism. I shall question both assertions, arguing that expressivism and naturalism fare no better than abolitionism with respect to the desiderata and that they ultimately collapse into variants of abolitionism.

\section{EXPRESSIVISM, NATURALISM, ABOLITIONISM, AND THE DESIDERATA}

Proponents of expressivism and naturalism maintain that their respective views do better than abolitionism at meeting the requirements any solution to the now-what problem should meet. In this section, I will argue that they are wrong. It will be my contention that every desideratum that they can satisfy can be satisfied just as well by abolitionists. My argument to this effect will be twofold. Expressivists and naturalists can characterize their views as being revisionary either about moral thought only or about moral thought and discourse, but they will fail to outperform abolitionism on both characterizations, albeit for different reasons. Let us examine each option in turn, starting with the latter.

Expressivists and naturalists sometimes speak as though we should revise our moral attitudes and talk. Not only should we replace our moral beliefs with conative attitudes or beliefs in natural facts; we should also replace recognizably moral discourse with discourse of another kind. As Svoboda explains in the case of expressivism:

One way of transitioning to revisionary expressivism is for participants in moral discourse to bring their moral language into line with some kind of 
expressivism.... The replacement moral discourse would be recognizably non-cognitivist. Instead of saying, "It is true that donating to charity is morally obligatory," one might say, "Hooray for donating to charity!" or "Donate to charity."

Likewise, a proponent of naturalism might maintain that, instead of saying that donating to charity is right, we should say that donating to charity maximizes pleasure and that, instead of saying that rape is wrong, we should say that rape generates significant distress. While the corresponding attitudes would be our revised moral thought, these sentences would constitute our revised moral language.

Whether or not it allows expressivism and naturalism to satisfy the desiderata listed in section 1, the problem with this move is that it is available to abolitionists too. Indeed, abolitionists do not merely urge us to dispense with moral thought and discourse. Because they recognize that morality fulfills a number of functions, they also advise us to adopt new tools for the same purposes. Thus, on Richard Garner's characterization of the view, "The moral abolitionist ... recommends that we abandon the practice, or better, replace it with some motivational aids that allow us to acknowledge and deal with things as they are." ${ }^{24}$ Although he is an abolitionist, Garner suggests that we "replace the moral overlay with more effective and less duplicitous devices." ${ }^{25}$ Likewise, according to Stephen Ingram, "The essence of the abolitionist position is a prohibition on uttering sentences and making judgements that ascribe moral properties to acts." ${ }^{26}$ Abolitionists are therefore at liberty to argue that we should replace our moral beliefs with conative attitudes or nonmoral beliefs, and our moral sentences with nonmoral sentences that would express those attitudes. Indeed, this would not amount to uttering sentences and making judgments that ascribe moral properties to acts.

One rejoinder consists in saying that the replacement thought and discourse would be moral, hence out of reach for the abolitionist, who enjoins us to get rid of anything moral. It is unclear, however, why we should think of the sentences "Hooray for donating to charity!" and "Rape generates significant distress" as moral sentences since they do not contain terms we generally think of as moral. Anticipating this objection, Svoboda argues that these sentences would remain moral insofar as they would express moral judgments. ${ }^{27}$ This answer would be

Svoboda, "Why Moral Error Theorists Should Become Revisionary Moral Expressivists," 63.

Garner, "Abolishing Morality," 504, emphasis added.

Garner, "Abolishing Morality," 505.

Ingram, “After Moral Error Theory, After Moral Realism," 231.

Svoboda, "Why Moral Error Theorists Should Become Revisionary Moral Expressivists," 63. 
fair enough if the judgments in question were recognizably moral. But are they? Thus far, we have never thought of our approval of donating to charity and our belief that rape generates distress as moral judgments. We have always thought of them as paradigmatic examples of non-judgment (in the case of the former) and non-moral judgment (in the case of the latter). There does not seem to be any reason why abolitionists should suddenly take these attitudes to be moral judgments and consequently dissuade us from using them in place of our flawed moral beliefs.

Lutz too seems vaguely aware of this worry. He addresses the objection on behalf of his subjective brand of naturalism, which he calls "substitutionism." On this view, we should replace our moral beliefs with beliefs about our attitudes of approval and disapproval. Acknowledging that we already have such attitudes and that the abolitionist has nothing to object to our having them, Lutz maintains that, "unlike the abolitionist, the substitutionist will replace every discarded moral belief with a new belief about his attitudes." ${ }^{28}$ Thus, "what is distinctive of the substitutionist approach is that it advocates for a kind of replacement procedure, where every moral belief is replaced by a corresponding belief about one's attitudes." 29 To generalize a bit, according to naturalism, we should not be satisfied with the nonmoral beliefs we already have; we should sometimes replace our moral beliefs with corresponding new beliefs in natural facts. Andthe rejoinder goes-abolitionists cannot subscribe to the latter recommendation, and fail as a result to meet the desiderata.

Now, two cases must be distinguished: either your nonmoral beliefs are already in line with your moral beliefs or they are not. Assuming that you believe that donating to charity is right, either you already believe that you approve of donating to charity or you do not. If you do, then following the naturalist's recommendation you will simply get rid of your belief that donating to charity is right. In this case, abolitionism and naturalism will provide you with the same piece of advice. Suppose now that, although you believe that donating to charity is right, you do not approve of donating to charity — and as a result do not believe that you approve of donating to charity. Then, following the naturalist's recommendation, you will get rid of your belief that donating to charity is right and start to believe that you approve of donating to charity - and start to in fact approve of donating to charity. ${ }^{30}$ But once again, nothing prevents the abolitionist from recommending the very same thing. Garner makes this quite explicit

Lutz, “The 'Now What' Problem for Error Theory,” 365-66.

Lutz, “The 'Now What' Problem for Error Theory," 366, emphasis added.

Otherwise, you would form a false belief, and naturalism would violate a requirement very similar to the first desideratum: although it would avoid moral error, it would lead to non- 
when he says, in the passage quoted above, that the abolitionist recommends that we replace our moral beliefs with motivational states that would prompt us to act in line with our previous moral beliefs. In this precise case, she would advise you to abandon your belief that donating to charity is right and form instead an attitude of approval vis-à-vis donating to charity, just as the subjectivist does. More generally, as long as expressivism and naturalism advise us to revise not only moral thought but also moral language, the tools they use to satisfy the desiderata are available to abolitionism as well.

Turn now to the second option expressivists and naturalists could pursue. Unlike the abolitionist, they might encourage us to continue using moral language but to endow moral terms and the sentences containing them with a different meaning. We should use moral sentences to express conative attitudes or beliefs in natural facts rather than beliefs in nonnatural facts. ${ }^{31}$ In the revised moral practice, the sentence "Donating to charity is right" would no longer express the belief that donating to charity is right (i.e., instantiates the nonnatural property rightness) but the approval of donating to charity or the belief that donating to charity maximizes pleasure. By contrast, the sentence "Rape is wrong" would no longer express the belief that rape is wrong (i.e., instantiates the nonnatural property wrongness) but the disapproval of rape or the belief that rape generates significant distress.

This option seemingly has, over the previous one, the advantage of allowing expressivists and naturalists to make recommendations that are out of reach for abolitionists. Indeed, while the idea here is to revise moral thought but keep moral language unchanged, abolitionists believe that we should dispense with both moral thought and language. Moreover, on this characterization of expressivism and naturalism, we would have a reason to call the replacement judgments "moral": they would be expressed by moral sentences (assuming that a sentence is moral insofar as it contains recognizably moral words-more on that below).

A problem remains. Even if expressivism and naturalism advise us to keep using moral words and sentences, they will meet the desiderata no better than abolitionism. For it is our thoughts-whether one calls them moral (as the expressivist and the naturalist do) or nonmoral (as the abolitionist does) - that would allow morality's function to be performed, not our language. It is our attitudes, not our utterances, that motivate us and provide us with reasons to act,

moral error. But if there is something bad with moral error, then that thing is surely shared by error more generally.

31 Svoboda, "Why Moral Error Theorists Should Become Revisionary Moral Expressivists," 63; Husi, "Against Moral Fictionalism," 89; Lutz, “The 'Now What' Problem for Error Theory," 366 . 
possibly in ways that are currently considered moral. It is between our respective mental states, not between our respective utterances, that disagreements take place - in the absence of a disagreement in attitude, a disagreement in utterances is a disagreement in appearance only. And it is arguably with our judgments, not our utterances, that we reason and make inferences. Accordingly, as long as expressivists or naturalists are in agreement with abolitionists about the attitudes we should have, their views will yield the same results: when it comes to the desiderata, all will succeed or all will fail.

Of course, abolitionists cannot satisfy all the requirements as they are phrased: although they might in principle give us reasons to act in ways that are generally considered acceptable, they cannot make moral motivation, moral disagreement, and moral reasoning possible. Still, they could secure the same kind of motivation, disagreement, and reasoning expressivists and naturalists deem important. In phrasing the desiderata in explicitly moral terms, expressivists and naturalists make it impossible from the start for the abolitionist to meet them. But then they beg the question. If their recommendations amount to those of abolitionism in substance, they simply cannot argue that some important requirement is not met by abolitionism on the grounds that it makes no room for moral motivation, moral disagreement, and moral reasoning. ${ }^{32}$

\section{MERE VARIANTS OF ABOLITIONISM}

I have just argued that expressivism and naturalism constitute no improvement over abolitionism in terms of the desiderata listed in section 1. Abolitionists can make use of all the tools expressivists and naturalists appeal to in order to satisfy these requirements. In the present section, my claim will be stronger. I will argue that expressivism and naturalism are actually versions of abolitionism. This will be my argument:

1. Unless their replacement attitudes are genuine moral judgments, expressivism and naturalism are mere variants of abolitionism.

2. Expressivism's and naturalism's replacement attitudes are not genuine moral judgments.

3. Therefore, expressivism and naturalism are mere variants of abolitionism. ${ }^{33}$

Perhaps expressivism and naturalism can meet other desiderata that abolitionism cannot. But the burden of proof lies on the expressivist and naturalist to show this to be the case.

33 For the sake of readability, I will focus on moral thought from now on. Bear in mind that the argument is intended to apply just as forcefully to moral discourse. 
Let me say a few words in support of each premise.

The first premise is prima facie plausible and does not require much argument. As we saw earlier, abolitionists only maintain that we should stop making moral judgments. They do not oppose our replacing these judgments with attitudes of another kind. Hence, if expressivists and naturalists advise us to replace our moral judgments with attitudes that, as a matter of fact, are not genuine moral judgments, they do not make any recommendation that the abolitionist needs to reject, and their views amount to different variants of abolitionism. To constitute authentic alternatives to abolitionism, expressivism and naturalism must recommend the making of genuine moral judgments (albeit revised ones).

Premise 2 calls for more support. According to the error theory's conceptual claim, moral judgments presuppose the existence of nonnatural facts. Importantly, this feature of them is supposed to be "nonnegotiable," in the sense that any judgment that does not presuppose the existence of nonnatural facts is not a genuine moral judgment—it is at best a "schmoral" judgment. ${ }^{34}$ This nuance is of the utmost importance for the error theory. If this feature of moral judgments were negotiable, then moral realists could rightly propose "reforming definitions" of moral terms. ${ }^{35}$ Moral judgments would survive the discovery that nonnatural facts do not exist just as motion judgments survived the discovery that absolute motion does not exist. ${ }^{36}$ Now, all this provides support for premise 2. The expressivist and naturalist replacement judgments would not presuppose the existence of nonnatural facts, meaning that they would not share with current moral judgments one of their nonnegotiable features. This, in turn, means that they would not be genuine moral judgments.

Here is an objection that might be raised against premise 1: even assuming that there would no longer be genuine moral judgments and sentences after the reforms advocated by expressivists and abolitionists, the word "wrong" would still be in use. Does this not show that expressivism and naturalism are incompatible with abolitionism? Are abolitionists not as much opposed to moral words as they are to moral judgments and sentences? In a sense they are, but this sense does not offer any help to the objector. Consider a variant of abolitionism according to which we should replace our moral judgments with beliefs in natural facts. Proponents of this view could legitimately recommend that we

34 Joyce, The Myth of Morality, 3-5, and "Moral Anti-Realism," 24.

35 Brandt, "A Theory of the Right and the Good"; Railton, "Moral Realism."

36 Joyce, The Myth of Morality, 96. Expressivists and naturalists presumably know how crucial this is to the error theory-in fact, most say it explicitly (Husi, "Against Moral Fictionalism," 81-82; Lutz, "The 'Now What' Problem for Error Theory," 363-65; Kalf, Moral Error Theory, $4-5,15-16)$. 
use a new term, say "rong," to express these beliefs. Now, "wrong” as used after the naturalistic replacement procedure and "rong" as used after the abolitionist replacement procedure would mean the very same thing. Under these circumstances, it would be far-fetched to hold that "wrong" is a moral term while "rong" is not. If one is a moral term and the other not, that must be in virtue of their meaning. The difference just cannot be the respective sounds we make when we utter them or the letters we respectively use when we write them down. In consequence, it would make no sense for abolitionists to object to our using the word "wrong." Premise 1 still stands.

As we saw in section 2, Svoboda seems to accept it. However, he objects to something like premise 2 along the following lines:

Whether this objection goes through depends on what makes some kind of judgment or discourse moral. If moral judgments necessarily involve beliefs, for example, then revisionary expressivist judgments are not genuinely moral ones. However, there is good reason to suspect that the best conceptions of what moral judgment and discourse can be are general enough to permit non-cognitivist varieties. After all, while traditional cognitivists reject the view that moral judgments and utterances are in fact non-cognitivist, this is grounded in their finding non-cognitivism problematic in some respect ... other than its alleged failure to deliver genuinely moral judgments and utterances. Further, in order to avoid begging the question against non-cognitivists (e.g., by defining a moral judgment in cognitivist terms), cognitivists initially must work with some conception of moral judgment or discourse that is general enough to be susceptible to both cognitivist and non-cognitivist accounts. These considerations suggest that moral non-cognitivism would yield judgments and utterances that are recognizably moral. ${ }^{37}$

I remain unconvinced by this reply. Svoboda is correct when he claims that one cannot ground the denial that moral judgments are conative attitudes in hermeneutic expressivism's failure to deliver proper moral judgments. Hermeneutic cognitivists must indeed identify some other problematic feature displayed by expressivism. But the feature in question must be such as to indicate that hermeneutic expressivism fails to deliver genuine moral judgments, or we would not have an argument against it.

As for Svoboda's assertion that, in order not to beg the question, "cognitivists initially must work with some conception of moral judgment or discourse

37 Svoboda, "Why Moral Error Theorists Should Become Revisionary Moral Expressivists," 65-66. 
that is general enough to be susceptible to both cognitivist and non-cognitivist accounts," it is beside the point. It may well be true but does not entail that cognitivists must end up with such a conception. As a matter of fact, error theorists accept the error theory because they end up with a much more specific conception of moral judgment and discourse. Indeed, the view that moral judgments ascribe nonnatural properties is typically a conclusion they reach by doing conceptual analysis rather than some sort of metaphysical investigation. When Joyce argues that this is a conceptually nonnegotiable feature of moral judgment, for instance, he relies on our conceptual intuitions, such as our intuition that a judgment presupposing only hypothetical reasons on the part of the agent or a judgment that would lack what he calls "practical clout" would not qualify as a moral judgment. ${ }^{38}$ Now, is he thereby begging the question against hermeneutic expressivists and naturalists? He would certainly be if he assumed from the very beginning that moral judgments state nonnatural facts. But this is not what he does: this claim is the conclusion of the piece of conceptual analysis he provides, not an assumption he makes from the outset. It is a conceptual truth that moral judgments state nonnatural facts, yet one that, on pain of begging the question, must be established rather than assumed.

Absent a better expressivist or naturalist rejoinder, it is safe to conclude that the attitudes with which these views advise us to replace our current moral judgments do not deserve to be called "moral." From this, it follows that expressivism and naturalism are not distinct views from abolitionism. Does this mean that all revisionary theories are similarly doomed to collapse into a variant of abolitionism? As we shall see now, fictionalism might well be an exception.

\section{WHAT ABOUT FICTIONALISM?}

As a reaction to the objection that their solution to the now-what problem is in the end a form of abolitionism, expressivists and naturalists may identify a companion in guilt in fictionalism. In fact, Husi does just that:

By the same token, however, one might equally wonder whether fictionalism represents but a version of abolitionism, surrendering morality nonetheless. After all, the fictionalist departing assumption is that morality is fatally flawed, in light of which moral discourse hardly could keep running just exactly as it did before this revelation. ${ }^{39}$

In short, if naturalism is a form of abolitionism, then so is fictionalism. Ulti-

38 Joyce, The Myth of Morality, 32, 42-43, and The Evolution of Morality, 57-64.

39 Husi, "Against Moral Fictionalism," 83. 
mately, such a rejoinder would rest on an argument analogous to that raised in section 4 against expressivism and naturalism, but this time targeting fictionalism:

4. Unless its replacement attitudes are genuine moral judgments, fictionalism is a mere variant of abolitionism.

5. Fictionalism's replacement attitudes are not genuine moral judgments.

6. Therefore, fictionalism is a mere variant of abolitionism.

On the face of it, this argument sounds plausible. Indeed, one might suspect that expressivism and naturalism meet this objection just because they are brands of revisionism and that, a fortiori, any revisionary theory would meet it, including fictionalism. This would be unconvincing as a rejoinder to the objection: should fictionalism reduce to abolitionism too, this would not rescue expressivism or naturalism. But I believe that this rejoinder fails for yet another reason: one particular form of fictionalism is immune to this objection.

You might recall from the introduction that fictionalism, broadly construed, is the view that we should replace our moral beliefs with fictional attitudes of some sort. Time has come to give some more flesh to this characterization. Because we entertain two kinds of attitudes vis-à-vis fictional works, there are two versions of fictionalism. Let me illustrate this with the TV show True Detective. In the storyline, detectives Rust and Marty investigate the murder of Dora Lange. You might then have either of two attitudes toward this specific fictional fact. On the one hand, you could adopt an external perspective and talk about the fiction; telling your friend about the plot, you might say, "Rust and Marty investigate the murder of Dora Lange." In this case, the fiction bit would figure in the content of your attitude: your attitude would be a proper belief, and its content would be the proposition In the fiction, Rust and Marty investigate the murder of Dora Lange. On the other hand, you might adopt a perspective internal to the fiction and properly engage with it. In a way, you would also think that Rust and Marty investigate the murder of Dora Lange. In that case, however, the fiction bit would appear in the mode rather than the content of your attitude: your attitude would have the proposition Rust and Marty investigate the murder of Dora Lange as its content, but it would not be a belief; it would be a "make-belief."

As indicated, this gives rise to two variants of fictionalism. Content fictionalism is the view that we should adopt vis-à-vis morality an external perspective akin to that which you adopt toward True Detective when you tell your friend about its plot: we should replace our moral beliefs with beliefs whose content would contain a fictional operator. ${ }^{40}$ Instead of believing that rape is wrong, say,

Nolan et al., "Moral Fictionalism versus the Rest." 
we should believe that rape is wrong in the moral fiction. Force fictionalism, by contrast, is the view that we should adopt vis-à-vis morality an internal perspective akin to the one you adopt toward True Detective when you truly engage with the narrative: we should replace our moral beliefs with make-beliefs whose contents would be genuine moral propositions. ${ }^{41}$ Instead of believing that rape is wrong, we should make-believe that rape is wrong.

In the present section, my claim will be that, while content fictionalism reduces to a variant of abolitionism, force fictionalism does not. If this is indeed correct, the latter is the only consistently revisionary solution available to the now-what problem. Since I accepted premise 1 earlier, I will now assume the truth of premise 4, lest I be accused of applying a double standard. Everything will therefore hinge on premise 5. To make my point, I will have to argue first that beliefs in propositions about a moral fiction would not deserve to be called "moral," and second that moral make-beliefs would.

Start with content fictionalism. Why think that its replacement attitudes would not be genuinely moral? For the same reason that had us conclude that expressivism's and naturalism's replacement attitudes would not. On this view, we should replace our moral judgments with beliefs about a moral fiction-the belief that rape is wrong, for instance, with the belief that rape is wrong in the moral fiction we have adopted. But beliefs about moral fictions do not state nonnatural facts: the belief that rape is wrong in the moral fiction we have adopted ascribes to rape the property of being wrong in the moral fiction we have adopted, and this property is as natural as the property of generating significant distress. Hence, content fictionalism's replacement attitudes do not share with moral judgments one of their nonnegotiable features, which means they are not genuine moral judgments. ${ }^{42}$

One might expect premise 5 to be true of force fictionalism too, but it is not. In order to make that clear, I will elaborate further on the notion of make-belief that is at play in this theory. The main proponent of the view distinguishes belief from make-belief as follows: ${ }^{43}$

Belief: $S$ believes that $P$ only if (i) $S$ has assented to $P$ in her most critical contexts, and (ii) $S$ is disposed to assent to $P$ in her most critical contexts.

Make-belief: $S$ make-believes that $P$ only if (i) $S$ is disposed to assent to $P$

Joyce, The Myth of Morality.

This was predictable since content fictionalism is essentially a form of naturalism. It advocates replacing our moral beliefs with a specific kind of nonmoral beliefs. Joyce, The Myth of Morality, 192-93. 
in some contexts, (ii) $S$ has assented to not- $P$ in some more critical context, and (iii) $S$ is disposed to assent to not- $P$ in her most critical context. ${ }^{44}$

Two clarifications are in order if one is to apprehend force fictionalism adequately. First, assent to a proposition must be understood as a mental act rather than a speech act. The distinction between belief and make-belief could thus be phrased in terms of acceptance: both attitudes dispose us to accept their content in some contexts; however, while beliefs dispose us to accept their content in our most critical contexts, make-beliefs dispose us to reject their content in those contexts. Second, in the relevant sense, for any pair of contexts $\langle C n, C m\rangle$, " $C n$ is more critical than $\mathrm{Cm}$ if and only if $\mathrm{Cn}$ involves scrutiny and questioning of the kinds of attitude held in $\mathrm{Cm}$ but not vice versa." 45 Accordingly, deliberative contexts are less critical than contexts in which we do metaethics because we make in the former an assumption that we question in the latter, the assumption that there are moral truths. To sum up, force fictionalism advises us to accept moral propositions in everyday deliberation and yet reject them while doing metaethics.

Let us return to the matter at hand. There is a sense in which force fictionalism's replacement judgments are not genuine moral judgments: moral make-beliefs are not moral beliefs. Still, two replies are available to the fictionalist. First, even though moral make-beliefs would not qualify as moral judgments because they are not judgments in the first place, they would nonetheless share moral judgments' nonnegotiable problematic feature since they would essentially be dispositions to accept genuine moral propositions, and thus to ascribe nonnatural properties, no less than our moral beliefs currently do. Since it is to the ascription of nonnatural properties that abolitionists object, this means that force fictionalism is incompatible with abolitionism.

Second, it should be acknowledged that fictional replacement judgments cannot count as moral judgments so long as one construes judgment as a kind of mental state, namely as belief. However, although this construal is widespread enough in the metaethical literature (which is why I have so far stuck to it for the sake of presentation), it is at best a benign simplification. Philosophers of mind do not equate judgments with beliefs; they generally take judgments to be

One might object that this characterization fails as an account of the ordinary notion of make-belief. Maybe it does, but this is immaterial to my argument. What matters for my argument is that the attitude I call "make-belief," and whose adoption force fictionalists recommend, involves genuine moral judgments — and, even more to the point, that abolitionists cannot recommend its adoption. Thanks to an anonymous referee for drawing this issue to my attention. 
those mental acts that our beliefs dispose us to perform. Even some metaethicists make this distinction, as testified by this passage from Sigrun Svavarsdóttir:

It seems more accurate to think of judgments as mental acts rather than mental states, although they are, of course, the onsets, expressions, or activations of mental states.... I distinguish between moral judgments and the corresponding mental states ... and talk about the former as manifesting the latter. ${ }^{46}$

Interestingly for our purposes, in this more accurate understanding of the notion of judgment, the acceptances mentioned in the respective characterizations of belief and make-belief above are judgments - they are the mental acts that our beliefs dispose us to perform or by which they are manifested in our most critical moments. Besides, and most significantly, the acceptances that our make-beliefs dispose us to make in everyday contexts are judgments, just like the acceptances that our beliefs dispose us to make in more critical contexts. And for a good reason: they are the same mental acts. As a result, the acceptances that our moral make-beliefs would dispose us to make in everyday deliberation are moral judgments no less than those our moral beliefs currently dispose us to make.

Provided that moral judgments are construed-following the dominant use in the philosophy of mind-as mental acts rather than states, force fictionalism therefore entails that we should continue to make moral judgments, although we should replace our moral beliefs with moral make-beliefs. This means that it is not a mere variant of abolitionism.

\section{CONCLUSION}

I have argued that three of the current four revisionary solutions to the nowwhat problem-namely expressivism, naturalism, and content fictionalismare actually mere variants of abolitionism. Because there is nothing especially moral about the attitudes and sentences with which their proponents advise us to replace our moral judgments and sentences, these recommendations are plainly compatible with the letter of abolitionism. Not only that: they are even faithful to its spirit, which recommends that we adopt new attitudes in place of our discarded moral beliefs. If all this is correct, then there are to this day only three distinct solutions to the now-what problem: abolitionism, conservationism, and force fictionalism. ${ }^{47}$ And the latter is the only revisionary option.

46 Svavarsdóttir, "Moral Cognitivism and Motivation," 167.

47 Or only two, if conservationism reduces to force fictionalism, as has been argued elsewhere (Jaquet and Naar, "Moral Beliefs for the Error Theorist?"). 
In the present contribution, I did not defend a particular solution to the now-what problem. Mine was merely a claim about the now-what debate. Still, I believe the claim in question has interesting implications in this debate. For if expressivism, naturalism, and content fictionalism are ultimately variants of abolitionism, then they must face the same objections it faces. For example, it has been argued by both conservationists and force fictionalists that proper moral discourse and thought bring with them advantages that we would have to dispense with should we abolish morality. Thus, moral judgments help us bolster self-control and prevent short-sighted rationalizations. ${ }^{48}$ According to some, moral thought and discourse are so central to our psychology and practices that their abolition would be virtually impossible to implement. ${ }^{49}$ If I am correct that expressivism, naturalism, and content fictionalism are variants of abolitionism, and that they cannot salvage proper moral thought and discourse, then one can expect them to face these worries no less than self-proclaimed abolitionists do. ${ }^{50}$

\author{
University of Montreal \\ francois.jaquet@umontreal.ca
}

\title{
REFERENCES
}

Blackburn, Simon. Spreading the Word: Grounding in the Philosophy of Language. New York: Oxford University Press, 1984.

Brandt, Richard. "A Theory of the Right and the Good." Amherst, NY: Prometheus, 1979.

Field, Hartry. Realism, Mathematics, and Modality. Oxford: Blackwell, 1989.

Garner, Richard. "Abolishing Morality." Ethical Theory and Moral Practice 10, no. 5 (November 2007): 499-513.

Hale, Bob. "Can Arboreal Knotwork Help Blackburn out of Frege's Abyss?" Philosophy and Phenomenological Research 65, no. 1 (July 2002): 144-49.

48 Joyce, The Myth of Morality, 215; Olson, Moral Error Theory, 195.

49 Nolan et al., "Moral Fictionalism versus the Rest," 307; Olson, Moral Error Theory, 180-81.

50 Several friends and colleagues read and commented on previous drafts of this paper. In particular, I would like to thank Henrik Ahlenius, Vuko Andrić, Erik Angner, Stina Björkholm, Krister Bykvist, Hannah Carnegy-Arbuthnott, Pablo Carnino, Florian Cova, Björn Eriksson, Hichem Naar, Jonas Olson, Niklas Olsson-Yaouzis, Peter Ryman, Nils Säfström, Silvan Wittwer, and two anonymous reviewers for this journal. I am also grateful to the Swiss National Science Foundation, which supported this work as part of the project "Normative Issues in Metaethics." 
Hinckfuss, Ian. The Moral Society: Its Structure and Effects. Canberra: Australian National University, 1987.

Husi, Stan. "Against Moral Fictionalism." Journal of Moral Philosophy 11, no. 1 (January 2014): 80-96.

Ingram, Stephen. "After Moral Error Theory, After Moral Realism." Southern Journal of Philosophy 53, no. 2 (June 2015): 227-48.

Jaquet, François, and Hichem Naar. "Moral Beliefs for the Error Theorist?" Ethical Theory and Moral Practice 19, no. 1 (February 2016): 193-207.

Joyce, Richard. The Evolution of Morality. Cambridge, MA: MIT Press, 2007. . "Moral Anti-Realism." Stanford Encyclopedia of Philosophy (Winter 2016). https://plato.stanford.edu/entries/moral-anti-realism/.

. The Myth of Morality. New York: Cambridge University Press, 2001.

Kalf, Wouter. Moral Error Theory. London: Palgrave Macmillan, 2018.

Lutz, Matt. "The 'Now What' Problem for Error Theory." Philosophical Studies 171, no. 2 (November 2014): 351-71.

Mackie, J. L. Ethics: Inventing Right and Wrong. New York: Penguin, 1977.

Nolan, Daniel, Greg Restall, and Caroline West. "Moral Fictionalism versus the Rest." Australasian Journal of Philosophy 83, no. 3 (2005): 307-30.

Olson, Jonas. "Getting Real about Moral Fictionalism." Oxford Studies in Metaethics, vol. 6, edited by Russ Shafer-Landau, 181-204. Oxford: Oxford University Press, 2011.

- Moral Error Theory: History, Critique, Defence. Oxford: Oxford University Press, 2014.

Railton, Peter. “Moral Realism.” Philosophical Review 95, no. 2 (April 1986): 163207.

Streumer, Bart. Unbelievable Errors: An Error Theory about All Normative Judgements. Oxford: Oxford University Press, 2017.

Svavarsdóttir, Sigrun. "Moral Cognitivism and Motivation." Philosophical Review 108, no. 2 (April 1999): 161-219.

Svoboda, Toby. "Why Moral Error Theorists Should Become Revisionary Moral Expressivists." Journal of Moral Philosophy 14, no. 1 (December 2017): 48-72. 